\title{
Professional drivers in London: a mortality study
}

\author{
R BALARAJAN,' M E McDOWALL ${ }^{2 *}$ \\ From the Clinical Epidemiology and Public Health Research Unit, ${ }^{1}$ Robens Institute, University of Surrey, \\ Guildford GU2 $5 X H$, and Medical Statistics Division, ${ }^{2}$ Office of Population Censuses and Surveys, London \\ $W C 2 B$ 6JP, UK
}

ABSTRACT A total of 3392 professional drivers in London were followed up in a prospective mortality study. There were significantly fewer deaths than expected from all causes (SMR 91, $\mathrm{p}<0.05)$, circulatory disease (SMR 75, p < 0.05), and accidents (SMR 61, p < 0.05). Lorry drivers showed excess deaths from stomach cancer (SMR 141, p < 0.05), lung cancer (SMR 159, p < 0.05), bronchitis, emphysema, and asthma (SMR 143, p < 0.05), a pattern not evident among taxi drivers. Mortality from bladder cancers, leukaemia, and other lymphatic cancers were raised in taxi drivers, though the results did not achieve statistical significance. The importance of the findings is discussed.

Recent evidence suggests that professional drivers are at increased risk of death from malignancies of the lung, bladder, and lymphatic tissue. A major review of occupational disease surveillance studies identified consistent excesses of lung cancer in motor vehicle drivers, listing this as the second priority (behind investigation of possible exposure to asbestos) for further research. ${ }^{1}$ This excess is confirmed by the most recent reviews of occupational mortality in Britain ${ }^{2}$ and the United States. ${ }^{3}$ There is evidence that professional drivers are heavy cigarette smokers, ${ }^{24}$ but it is not clear whether this, or some synergistic effect of smoking and occupational exposures, account for the excess mortality. ${ }^{15}$

Excess risk of bladder cancer in those exposed to vehicle (especially diesel) exhaust fumes has been reported ${ }^{67}$ and several studies have indicated raised risk for professional drivers. Three separate casecontrol studies, in Detroit, ${ }^{8}$ London, ${ }^{9}$ and New England, ${ }^{10}$ each investigating local excesses of bladder cancer have found raised relative risks for drivers. Both the Detroit and New England studies were able to control for cigarette smoking but the association persisted. Other studies have, however, failed to show such an association between driving occupations and bladder cancer. ${ }^{11} 12$

Two studies have shown raised mortality from lymphatic neoplasms in truck drivers, ${ }^{1314}$ a finding receiving some support from analyses of routine

*Present address: Clinical Epidemiology and Public Health Research Unit, University of Surrey.

Accepted 22 July 1987 mortality ${ }^{15}$ and cancer registration ${ }^{16}$ data although not from others. ${ }^{3}$

To investigate these possibilities further, a prospective study of professional drivers was undertaken.

\section{Materials and methods}

The National Health Service Central Register (NHSCR) provides a source of data on the occupations of all men and women in 1939 and the ability (with one reservation covered later) to follow up the mortality of the 1939 population to date. 1939 records are stored in geographical order, and to facilitate the identification of drivers the study centred on those London boroughs where a higher than average proportion of the population was engaged in driving, according to the 1931 and 1951 censuses of populations. It was estimated that a minimum of 3000 drivers would be necessary in the study to provide adequate power for detecting a twofold or greater risk from bladder cancer and lymphatic neoplasms. Boroughs were selected randomly from those chosen according to the above criteria and were included in turn in the study until the inclusion of all eligible drivers from that borough took the study total to over 3000 . The boroughs included were the City of London, Bethnal Green, Stepney, and Southwark. For these boroughs, records were extracted for men whose occupational description was bus, coach, lorry, or taxi driver. Delivery men and van drivers were excluded to try and concentrate the study on those drivers who needed special commercial licences for their driving. It was reasoned that these men would be more likely than 
Table 1 Standardised mortality ratios (SMRs) for major causes of death among professional drivers in London (1950-84)

\begin{tabular}{|c|c|c|c|c|}
\hline & $\begin{array}{l}\text { All drivers } \\
S M R \text { (Deaths) }\end{array}$ & $\begin{array}{l}\text { Taxi drivers } \\
\text { SMR (Deaths) }\end{array}$ & $\begin{array}{l}\text { Bus and coach drivers } \\
\text { SMR (Deaths) }\end{array}$ & $\begin{array}{l}\text { Lorry drivers } \\
\text { SMR (Deaths) }\end{array}$ \\
\hline $\begin{array}{l}\text { All causes } \\
\text { Malignant neoplasms } \\
\text { Circulatory disease } \\
\text { Respiratory disease } \\
\text { Accidents }\end{array}$ & $\begin{array}{r}91 *(2182) \\
122 *(679) \\
75^{*}(890) \\
110(404) \\
61 *\left(\begin{array}{r}39)\end{array}\right.\end{array}$ & $\begin{array}{l}86^{*}(370) \\
107(98) \\
82^{*}(181) \\
74^{*}(51) \\
29\left(\begin{array}{r}(3)\end{array}\right.\end{array}$ & 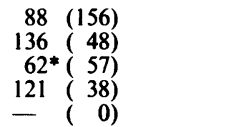 & $\begin{array}{c}93^{*}(1656) \\
125^{*}(533) \\
74(597) \\
117^{*}(315) \\
73(36)\end{array}$ \\
\hline
\end{tabular}

${ }^{*} \mathrm{p}<0.05$.

Table 2 Standardised mortality ratios (SMRs) for selected cancers among professional drivers in London (1950-84)

\begin{tabular}{|c|c|c|c|c|}
\hline & $\begin{array}{l}\text { All drivers } \\
S M R \text { (Deaths) }\end{array}$ & $\begin{array}{l}\text { Taxi drivers } \\
\text { SMR (Deaths) }\end{array}$ & $\begin{array}{l}\text { Bus and coach drivers } \\
S M R \text { (Deaths) }\end{array}$ & $\begin{array}{l}\text { Lorry drivers } \\
\text { SMR (Deaths) }\end{array}$ \\
\hline $\begin{array}{l}\text { Cancer of stomach } \\
\text { Cancer of lung } \\
\text { Cancer of bladder } \\
\text { Leukaemia } \\
\text { Other lymphatic neoplasms }\end{array}$ & $\begin{array}{l}130 *(89) \\
147 *(328) \\
105(25) \\
106(12) \\
98(16)\end{array}$ & $\begin{aligned} 68 & (8) \\
86 & (30) \\
121 & (5) \\
164 & (3) \\
161 & (4)\end{aligned}$ & $\begin{array}{r}168(8) \\
142(18) \\
58(1) \\
-\quad(0) \\
-\quad(0)\end{array}$ & 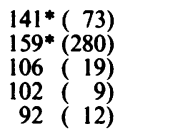 \\
\hline
\end{tabular}

${ }^{*} \mathrm{p}<0.05$.

other drivers to stay in the same occupation and would thus have longer exposure to any hazards of driving. For each driver selected, information on date of birth and where relevant date of death was obtained. In the latter event the death certificates were obtained and cause coded to the underlying cause of death according to the 8th revision of the International Classification of Diseases. ${ }^{17}$

Records extracted from NHSCR included dates of emigration but no details of any temporary absences due to service in the armed forces or short term emigration during and immediately after the second world war. Deaths during these absences are unlikely to have been recorded at NHSCR and thus an analysis from 1939 could have produced an overestimate of person-years at risk. Consequently the date of entry to the study was taken as being 1 January 1950 and only those drivers recorded as being alive at that date were included in the study. This date was chosen for two reasons: (1) record keeping arrangements in connection with the start of the NHS make it possible to identify those 1939 drivers alive at that date and (2) to avoid difficulties in obtaining comparable reference rates for periods before 1950 due to changes in the ICD classifications. Person-years at risk were calculated from 1 January 1950 until the end of 1984 or to the date of death or emigration. Expected numbers of deaths were calculated on the basis of the corresponding male death rates for England and Wales, converted to ICD 8th revision. The observed and expected deaths were compared in the form of a ratio and $95 \%$ confidence intervals calculated.

\section{Results}

The study population consisted of the 3392 men known to have been alive on 1 January 1950 of the 3978 originally identified drivers. Of these 3392 men, 2182 had died by the 31 December 1984.

Standardised mortality ratios (SMRs) for major causes of death are presented in table 1 for all drivers and the different groups. For drivers as a whole, there were significant deficits in mortality from all causes, circulatory disease, and accidents, and significant excesses from cancers and bronchitis. This pattern was reflected among bus, coach, and lorry drivers but not among taxi drivers who had significantly lower mortality from all causes, circulatory disease, and res-

Table 3 Standardised mortality ratios (SMRs) for selected diseases among professional drivers in London (1950-84)

\begin{tabular}{lcccc}
\hline & $\begin{array}{l}\text { All drivers } \\
\text { SMR (Deaths) }\end{array}$ & $\begin{array}{l}\text { Taxi drivers } \\
\text { SMR (Deaths) }\end{array}$ & $\begin{array}{l}\text { Bus and coach drivers } \\
\text { SMR (Deaths) }\end{array}$ & $\begin{array}{l}\text { Lorry drivers } \\
\text { SMR (Deaths) }\end{array}$ \\
\hline $\begin{array}{l}\text { Ischaemic heart } \\
\text { disease }\end{array}$ & $83^{*}(571)$ & $104(122)$ & $58^{*}(27)$ & $81^{*}(422)$ \\
$\begin{array}{l}\text { Stroke } \\
\begin{array}{l}\text { Bronchitis, ephysema } \\
\text { and asthma }\end{array}\end{array}$ & $60^{*}(152)$ & $63^{*}(31)$ & $55^{*}(12)$ & $60^{*}(109)$ \\
\hline
\end{tabular}

${ }^{*} \mathrm{p}<0.05$. 
piratory disease with a slight non-significant excess of cancers.

Cancers of the stomach and lung were significantly higher in the study group again reflected among lorry, bus, and coach drivers (table 2). SMRs for cancer of the bladder ( 105 on 25 cases) and leukaemia (106 on 12 cases) did not significantly differ from 100 in the study. Taxi drivers in contrast showed deficits of lung and stomach cancer but notably higher mortality than the other groups (although not significantly so) for bladder cancer (SMR 121 on five cases), leukaemias (SMR 164 on three cases), and other lymphatic and haematopoietic neoplasms (SMR 161 on four cases).

All groups in the study experienced low mortality from ischaemic heart disease (except taxi drivers) and stroke (table 3). Deaths from bronchitis, emphysema, and asthma were significantly higher in bus, coach, and lorry drivers but not in taxi drivers. Bus, coach, and lorry drivers' mortality patterns were similar and broadly reflect the overall study results - the all drivers data being strongly influenced by lorry drivers who contributed to over $75 \%$ of the deaths in the study.

\section{Discussion}

This study followed the mortality of a group of men identified as professional drivers from 1950 to 1984 . Its major limitation is the lack of any quantification of exposure to any of the potential hazards of driving.

Men were selected for this study on the basis of their occupational descriptions in 1939 which suggested that they may have needed special commercial licences for driving. It was assumed that these professional drivers were likely to have remained drivers for much of their working life - the possession of such a licence being a valuable asset. No direct measure of duration of exposure for the study group is available. Of the men dying between 1950 and 1984 , nearly $60 \%$ were recorded as drivers on the death certificate, indicating that they were either still driving at the time of death or had driven until retirement. This figure varied according to the occupational group, with nearly $85 \%$ of death certificates of taxi drivers recording that occupation. Comparable figures for the other groups were $68 \%$ for bus and coach drivers and $52 \%$ for lorry drivers.

A further limitation of the study is the use of national death rates to calculate expected mortality for a specific occupational group living in an inner city area. Adequate reference rates by social class and area were not available for a sufficient period to permit more relevant reference rates to be used. All professional drivers would be classified in social class IIIM (skilled manual workers) in the Registrar General's classification. ${ }^{18}$ This class generally experienced only slightly higher male mortality levels than the national population, the major exception being for lung cancer where the SMR for men aged 15-64 in England and Wales, for deaths from 1970 to 1972 , was $118 .{ }^{19}$ Allowance for differences between nationally expected mortality and that in the London boroughs covered in the study is less straightforward-for instance, in 1969-73 the borough of Southwark was in the ten county and London boroughs with the highest male mortality from lung cancer (SMR 146), ${ }^{20}$ whereas the SMR for lung cancer in Greater London was $118^{20}$

Given the social class and area characteristics of the study population, the study SMR of 147 for lung cancer might therefore appear explicable in terms of non-occupational exposures including smoking and urban risk factors. Lung cancer mortality, however, is high only for bus, coach, and lorry drivers, taxi drivers showing a (non-significant) deficit. That this is probably accounted for by low smoking levels in taxi drivers is suggested also by the low ratios for bronchitis, emphysema, and asthma compared with the other drivers. Previous evidence on lung cancer excess in drivers has noted data on high rates of smoking ${ }^{245}$ and also on the carcinogenic properties of exhaust gases. ${ }^{2122}$ Of the three groups of drivers in this study, taxi drivers could be expected to have the greatest exposure to exhaust gases as their work is usually within urban areas, whereas bus, coach, and lorry drivers may to a greater extent spend periods on the open road away from concentrations of traffic. If these crude assessments of likely exposure are correct the study results suggest that the excesses of lung cancer in the bus, coach, and lorry drivers are most likely due to higher smoking levels, or perhaps some synergistic effect between smoking and exhaust fumes, ${ }^{5}$ but not to any direct independent effect of exhaust fumes. This may support the findings of a case-referent study where non-smoking drivers had no significant excess of lung cancer (although the odds ratio was above one).$^{14}$ Further evidence on lung cancer risks in professional drivers will clearly have to account for smoking status to contribute further to this question.

The overall SMR for bladder cancer in this study is 105 on 25 cases providing no support for the association found in other studies. ${ }^{8-10}$ The SMR for taxi drivers, hypothesised as suffering the greatest exposure to fumes, is high (121 on five cases) but not significantly so. Given that the Greater London SMR for this condition in men in $1969-73$ was $116,{ }^{20}$ this ratio could easily be within expected levels. The third hypothesised disease associated with professional driving was lymphatic neoplasms. Again this study shows no excess mortality for all drivers combined, only taxi drivers having raised SMR (161 on four cases) although this was not significant. Further evidence is needed to confirm or refute this hypothesis.

One unexpected result from this study is the consis- 
tently low mortality from motor vehicle traffic accidents which is contrary to the evidence of general mortality reviews in England and $\mathrm{Wales}^{2}$ and the USA. ${ }^{3}$ These reviews, however, generally include van drivers or other delivery men, or both, in their occupational groupings. That our study group has a low traffic accident mortality may be attributable to the professionalism of their driving.

\section{References}

1 Dubrow R, Wegman DH. Setting priorities for occupational cancer research and control: synthesis of the results of occupational disease surveillance studies. JNCI 1983;71: 1123-42.

2 Office of Population Censuses and Surveys. Decennial supplement-occupational mortality 1979, 1980 and 1982, 1983 Great Britain, London: HMSO, 1986.

3 US Department of Health and Human Sciences. Mortality patterns among US veterans by occupation and smoking status. Bethesda: National Institute of Health, 1985. (NIH 85-2756.)

4 Sterling TD, Weinkam JJ. Smoking characteristics by type of employment. J Occup Med 1976;18:743-54.

5 Damber L, Lavsson LG. Professional driving, smoking and lung cancer: a case referent study. $B r J$ Ind Med 1985;42:246-52.

6 Howe GR, Burch UD, Miller AB, et al. Tobacco use, occupation, coffee, various nutrients and bladder cancer. $\mathrm{JNCI}$ 1980;64:701-13.

7 Wynder EL, Onderdonk J, Mantel N. An epidemiological investigation of cancer of the bladder. Cancer 1963;16:1388-1407.

8 Silverman DT, Hoover RN, Albert S, Graff KM. Occupation and cancer of the lower urinary tract in Detroit. $J N C I$ 1983;70: 237-45.
9 Baxter PJ, McDowall ME. Occupation and cancer in London: an investigation into nasal and bladder cancer using the Cancer Atlas. Br J Ind Med 1986;43:44-9.

10 Hoar SK, Hoover R. Truck driving and bladder cancer mortality in rural New England. $J N C I$ 1985;74:771-4.

11 Dunham LJ, Rabson AS, Stewart HL, Frank AS, Young JL. Rates, interview and pathology study of cancer of the urinary bladder in New Orleans, Louisiana. JNCI 1968;41:683-709.

12 Anthony HM, Thomas GM. Tumours of the urinary bladder: an analysis of the occupations of 1030 patients in Leeds, England. JNCI 1970; 45:879-95.

13 Rushton L, Alderson MR. Epidemiological survey of oil distribution centres in Britain. Br J Ind Med 1983;40:330-9.

14 Howe GR, Lindsay JP. A follow-up study of a ten percent sample of the Canadian labour force: I. Cancer mortality in males 1965 73. JNCI 1983;70:37-44.

15 Balarajan R, McDowell ME. Malignant lymphomas and road transport workers. J Epidemiol Community Health 1983;37: 316-7.

16 Balarajan R. Malignant lymphomas in road transport workers. $J$ Epidemiol Community Health 1983;37:279-80.

17 World Health Organisation. International classification of diseases. 9th rev. Geneva: WHO, 1977.

18 Office of Population Censuses and Surveys. Classification of occupations 1970. London: HMSO, 1970.

19 Office of Population Censuses and Surveys. Decennial supplement-occupational mortality 1970-1972. London: HMSO, 1978.

20 Office of Population Censuses and Surveys. Decennial supplement-area mortality 1969-73. London: HMSO, 1981.

21 Schenker MB. Diesel exhaust-an occupational carcinogen? J Occup Med 1980;22:41-6.

22 Wong O, Morgan RW, Kheifels L, Larson SR, Whorton MD. Mortality among members of a heavy construction equipment operators union with potential exposure to diesel exhaust emissions. Br J Ind Med 1985;42:435-48. 